\title{
Excretion of Lipoteichoic Acid by Group A Streptococci
}

\author{
INFLUENCE OF PENICILLIN ON EXCRETION AND LOSS OF ABILITY \\ TO ADHERE TO HUMAN ORAL MUCOSAL CELLS
}

\author{
Michael L. Alkan and Edwin H. Beachey, Veterans Administration Hospital \\ and the Department of Medicine, University of Tennessee Center \\ for the Health Sciences, Memphis, Tennessee 38104
}

\begin{abstract}
A в S T R A C T Group A streptococci were grown in the presence of $\left[2-{ }^{3} \mathrm{H}\right]$ glycerol. Concentrated suspensions of the labeled organisms were incubated with and without penicillin. $\left[{ }^{3} \mathrm{H}\right]$ Glycerol-labeled material accumulated in the supernates in increasing amounts with increasing concentrations of penicillin, ranging from 0 to $50 \mathrm{U} / \mathrm{ml}$. The excretion of labeled material occurred in the absence of nucleic acid synthesis or bacteriolysis indicating that the phenomenon is independent of cell multiplication or decay. The accumulation of label was paralleled by an accumulation of erythrocyte-sensitizing material measured by passive hemagglutination tests for lipoteichoic acid antigen, indicating that a portion of the labeled material possessed the properties of lipoteichoic acid. Culture supernates were fractionated by column chromatography, and the materials obtained were analyzed by electrophoresis on sodium dodecyl sulfate polyacrylamide, thin-layer chromatography, and paper chromatography. The ability of the same materials to bind to human erythrocytes and epithelial cells was tested. The culture supernate contained lipoteichoic acid, deacylated lipoteichoic acid, glycerol phosphate, and free glycerol. Penicillin caused an increase in the amounts of each of the excreted materials. Streptococci that were stimulated with penicillin to lose their lipoteichoic acid (previously shown to mediate adherence of group A streptococci) lost their ability to adhere to buccal mucosal cells, suggesting that penicillin may influence bacterial ecology by mechanisms other than killing sensitive organisms.
\end{abstract}

Dr. Beachey is a recipient of a Medical Investigatorship award from the Veterans Administration.

Received for publication 29 June 1977 and in revised form 4 November 1977.

\section{INTRODUCTION}

Gram-positive bacteria have been shown to excrete lipoteichoic acid (LTA) ${ }^{1}$ into their culture medium (13). It has been suggested that penicillin stimulates the process thereby triggering bacterial autolytic murein hydrolases (4). Recently, however, Horne and Tomasz (1) reported that penicillin stimulates the excretion of LTA from Streptococcus sanguis without inducing autolysis or killing. They postulated that the organisms were "autolysin defective" or that the murine hydrolases respond in a different manner to penicillin. The ability of bacteria to release LTA into the culture supernate was of special interest to us because we recently presented evidence to suggest that LTA exposed on the surface of organisms mediates the binding of streptococci to human oral mucosal cells $(5,6)$.

In the present paper we describe the in vitro excretion of LTA by group A streptococci incubated in the presence of various concentrations of penicillin. Excretion was monitored by $(a)$ the release of $\left[{ }^{3} \mathrm{H}\right] \mathrm{glyc}-$ erol-labeled material, $(b)$ the epithelial cell membranebinding activity of the excreted material, and $(c)$ the capacity of the material to modify erythrocytes to enable agglutination with antiserum to LTA. Among the glycerol-containing materials excreted by the streptococci, we were able to identify LTA. The excretion of these materials was enhanced by penicillin. Concomitant with the release of LTA, the penicillin-treated organisms lost their ability to adhere to human oral mu-

\footnotetext{
'Abbreviations used in this paper: CFU, colony-forming units; $\left[{ }^{3} \mathrm{H}\right] \mathrm{LTA},\left[{ }^{3} \mathrm{H}\right]$ glycerol-labeled lipoteichoic acid; LTA, lipoteichoic acid; PBS, $0.02 \mathrm{M}$ phosphate/0.154 M NaCl, pH 7.4; PHA, passive hemagglutination; RBC, erythrocytes; SDS, sodium dodecyl sulfate; THB, Todd-Hewitt broth; TLC, thinlayer chromatography.
} 
cosal cells in the absence of significant changes in the viability or integrity of the streptococci.

\section{METHODS}

Streptococci. The type 24 strain of group A streptococci isolated from a patient who subsequently developed acute rheumatic fever was previously described (7). Strain 1RP41 (T type $28, M$ type 13) of group A streptococci was kindly furnished by Dr. Rebecca Lancefield, The Rockefeller University, New York. Stock cultures were stored frozen $\left(-70^{\circ} \mathrm{C}\right)$ in Todd-Hewitt broth (THB; Difco Laboratories, Detroit, Mich.) supplemented with $20 \%$ rabbit serum.

Extraction of LTA from streptococci. The 1RP41 strain of streptococci has been shown to yield satisfactory quantities of relatively pure teichoic acid (8). The organisms were grown in batches of 15 liters in $\mathrm{THB}$ at $37^{\circ} \mathrm{C}$ for $24 \mathrm{~h}$, collected by continuous-flow centrifugation (Ivan Sorvall, Inc., Norwalk, Comn.), and washed three times in distilled water. LTA was extracted by the method of Moskowitz (8) with minor modifications as previously described (6). The purity of the LTA obtained by this method was assessed by gas-liquid chromatography, thin-layer chromatography (TLC), and chemical analysis of amino acids, glycerol, fatty acids, and carbohydrates as previously described (6). Analysis showed glycerol, fatty acids, and alanine in a ratio consistent with LTA. Amino acid analysis showed the presence of alanine only.

$\left[{ }^{3} \mathrm{H}\right]$ Glycerol-labeled LTA $\left.\left({ }^{3} \mathrm{H}\right] \mathrm{LTA}\right)$ was prepared by growing the organisms in THB supplemented with $2 \mathrm{mCi} /$ liter of $\left[2-{ }^{-3} \mathrm{H}\right]$ glycerol (New England Nuclear, Boston, Mass.; sp act 20()$\mu \mathrm{Ci} / \mathrm{mmol}$ ) for $16 \mathrm{~h}$ at $37^{\circ} \mathrm{C}$. The labeled LTA was extracted as referred to above. In some experiments, samples of $\left[{ }^{3} \mathrm{H}\right]$ LTA were hydrolyzed with ammonia as previously described (6). To $0.5 \mathrm{ml}$ of a $1-\mathrm{mg} / \mathrm{ml}$ solution of LTA an equal volume of $30 \% \mathrm{NH}_{4} \mathrm{OH}$ (Fisher Scientific Co., Pittsburgh, Pa.) was added and incubated for $16 \mathrm{~h}$ at $24^{\circ} \mathrm{C}$. LTA hydrolyzed in this way was previously shown to retain its antigenic properties indicating that the polyglycerolphosphate backbone was not degraded (6). The mixture was lyophilized and redissolved in $0.5 \mathrm{ml} 0.02 \mathrm{M}$ phosphate/0.154 M NaCl, pH 7.4 (PBS).

Tests of supernates for excretion of radiolabeled material from $\left[{ }^{3} \mathrm{H}\right]$ glycerol-labeled streptococci. Type 24 streptococci were grown overnight in THB, and subcultured 1:20 in 20() $\mathrm{ml}$ of fresh THB supplemented with $0.5 \mathrm{mCi}$ of $\left[2-{ }^{3} \mathrm{H}\right]-$ glycerol and grown for $16 \mathrm{~h}$ at $37^{\circ} \mathrm{C}$. The cells were harvested and washed three times in PBS by centrifugation at 15,000 $g$ for $10 \mathrm{~min}$ at $4^{\circ} \mathrm{C}$. The washed cells were resuspended in $10 \mathrm{ml}$ of fresh THB. Labeled streptococci suspended in this manner were used for all further experiments. Penicillin in increasing concentrations was added to 2 - $\mathrm{ml}$ samples of the suspension, and the suspensions were then incubated at $37^{\circ} \mathrm{C}$. Samples $(0.15 \mathrm{ml})$ were removed at time intervals of $30 \mathrm{~min}$ for $3 \mathrm{~h}$. Each of the samples was centrifuged at $8,000 \mathrm{~g}$ for $2 \mathrm{~min}$, and $0.1 \mathrm{ml}$ of the supernate was removed, dissolved in $5 \mathrm{ml}$ Aquasol (New England Nuclear), and analyzed in a liquid scintillation counter (Nuclear-Chicago, Des Plaines, Ill.).

To estimate the degree of growth and bacterial lysis during the above experiments, the incorporation and the release of "H-labeled thymidine were determined as a function of the concentration of bacteria in THB. Equal quantities of washed sedimented streptococci were resuspended in increasing volumes of fresh THB supplemented with $1 \mu \mathrm{Ci}\left[{ }^{3} \mathrm{H}\right]$ thymidine/ $\mathrm{ml}$ (New England Nuclear; sp act $1 \mathrm{Ci} / \mathrm{mmol}$ ) and incubated for $3 \mathrm{~h}$ at $37^{\circ} \mathrm{C}$. As controls, duplicate cultures were incubated at $4^{\circ} \mathrm{C}$. Cells were sedimented and washed three times in ice-cold PBS and then dissolved in scintillation fluid and counted as described above. To estimate lysis, the organisms were grown for $16 \mathrm{~h}$ at $37^{\circ} \mathrm{C}$ in the presence of $1 \mu \mathrm{Ci} / \mathrm{ml}$ of $\left[{ }^{3} \mathrm{H}\right]$ thymidine. The washed streptococci were resuspended in increasing volumes of THB containing $0.5 \mu \mathrm{g} / \mathrm{ml}$ of penicillin. The suspensions were incubated for $3 \mathrm{~h}$ at $37^{\circ} \mathrm{C}$, and culture supernates were analyzed for radioactivity as described above.

Assays of erythrocyte-sensitizing and binding activity of material in culture supernates. The membrane-sensitizing activities of the culture supernates were assayed by mixing serial dilutions of the test substances (heat-inactivated at $56^{\circ} \mathrm{C}$ for $30 \mathrm{~min}$ ) with $0.05 \mathrm{ml}$ of a washed $2 \%$ suspension of group $\mathrm{O}$, human erythrocytes (RBC) as previously described (6). The mixtures were incubated for $30 \mathrm{~min}$ at $37^{\circ} \mathrm{C}$. The $\mathrm{RBC}$ in each tube were then washed twice in PBS and resuspended in 0.2 $\mathrm{ml}$ of antiserum to LTA diluted 1:160. The mixtures were incubated for $30 \mathrm{~min}$ at $37^{\circ} \mathrm{C}$ followed by centrifugation at $1,000 \mathrm{~g}$ for $5 \mathrm{~min}$. The buttons were gently shaken and agglutination recorded. The reciprocal of the highest dilution of test solution that sensitized RBC was designated the passive hemagglutination (PHA) titer.

Column chromatography. Equal volumes of culture supernate and $96 \%$ phenol (Fisher Scientific Co.) were adjusted to $\mathrm{pH} 4.7$ with $0.1 \mathrm{~N} \mathrm{HCl}$. Mixtures were shaken and incubated at $4^{\circ} \mathrm{C}$ for $1 \mathrm{~h}$ and centrifuged at $15,000 \mathrm{~g}$ for $20 \mathrm{~min}$ at $4^{\circ} \mathrm{C}$. The aqueous phase was collected, freeze-dried, and resuspended in $1 \mathrm{ml}$ of $0.2 \mathrm{M}$ ammonium acetate buffer. The concentrated aqueous phase of the phenol-extracted culture supernate was placed on a $1.5 \times 90-\mathrm{cm}$ column of Sepharose 6 B (Pharmacia Fine Chemicals, Piscataway, N. J.) equilibrated with $0.2 \mathrm{M}$ ammonium acetate containing $0.02 \%$ sodium azide. The void and total volumes were determined by elution of blue dextran (Pharmacia Fine Chemicals) and tritiated water, respectively. The positions for the elution of LTA and deacylated LTA were determined by eluting tritium-labeled preparations of the purified materials. 2-ml fractions were collected with the same buffer and $0.5-\mathrm{ml}$ aliquots were mixed with $5 \mathrm{ml}$ of scintillation liquid and analyzed as described above. The fractions were pooled according to their radioactivity, freeze-dried, and resuspended in $1 \mathrm{ml}$ of PBS.

Analytical methods. Electrophoresis in sodium dodecyl sulfate (SDS) polyacrylamide was performed according to the method described by Weber and Osborn (9). Samples of peaks obtained by column chromatography were placed on a slab gel of $15 \%$ polyacrylamide containing $0.1 \%$ SDS. Slices of the gel $1.2 \mathrm{~mm}$ in length were placed in toluene scintillation fluid with PPO and counted as previously described.

TLC was carried out according to the method described by Skipski and Barclay (10) on silica gel G plates (Merck \& Co., Inc., Rahway, N. J.; $0.25 \mathrm{~mm}$ ) using chloroform, methanol, and water $(65: 25: 4)$. Areas of $1 \mathrm{~cm}$ were scraped off into vials containing scintillation fluid, and counted as described above.

Paper chromatography was performed utilizing the ascending method in a solvent containing propanol, ammonium hydroxide, and water $(6: 3: 1)$. The paper was cut into $0.7-\mathrm{cm}$ segments, and each was placed in scintillation fluid and counted as described above.

Membrane-binding properties of column fractions. Oral epithelial cells were prepared as previously described $(5,11)$. Scrapings of the buccal mucosa were obtained by gently scraping buccal mucosa with a wood spatula. The scrapings were washed three times in PBS, and $10^{5}-10^{6}$ cells were used in each experiment. RBC were washed in PBS, and $10^{7}$ cells were used in each experiment. These cells were incubated with column fractions containing $700-1,000 \mathrm{cpm}$ of $\left[{ }^{3} \mathrm{H}\right] \mathrm{glyc}-$ erol-containing material in a total volume of $0.2 \mathrm{ml}$ for $30 \mathrm{~min}$ at $37^{\circ} \mathrm{C}$. The suspensions were poured onto a membrane filter (Millipore Corp., Bedford, Mass.) with a pore size of $0.45 \mu \mathrm{m}$. The cells on the filters were washed with PBS. Filters were 
dissolved in $5 \mathrm{ml}$ of scintillation fluid and counted as described.

Epithelial cell adherence of penicillin-treated streptococci. The ability of untreated and penicillin-treated streptococci to bind to human oral mucosal cells was assayed by a modification (6) of the method originally described by Gibbons and Van Houte (12). Epithelial cells obtained from three healthy donors were pooled, washed, and resuspended in PBS. Streptococci, $10^{9}$, were exposed to $10^{5}$ epithelial cells. Nonadherent bacteria were removed by repeated differential centrifugation. Results are expressed as mean number of bacteria adherent per epithelial cell.

Antisera. Antisera were raised in rabbits against LTA as previously described (5). Purified LTA was precipitated with methylated bovine serum albumin. The precipitate was suspended in PBS and emulsified in an equal volume of incomplete Freund's adjuvant. The emulsion was mixed with an equal volume of $2 \%$ Tween 80 , (ICI United States Inc., Wilmington, Del.), and injected subcutaneously into New Zealand white rabbits as previously described (5). Antisera to LTA were tested by the PHA of human RBC sensitized with LTA (6).

\section{RESULTS}

Recent studies (1) have indicated that in the log phase of growth, streptococci excrete LTA in response to

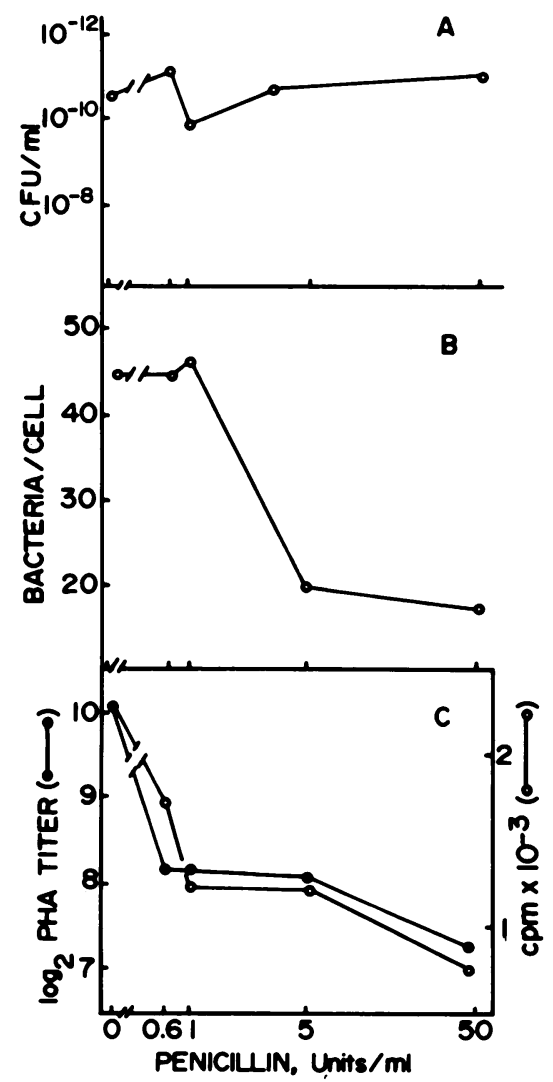

FIGURE 1 Influence of penicillin on viability (A), bacterial adherence to oral epithelial cells (B), and LTA content (C) of streptococci. LTA content is expressed as radiolabeled extractable LTA $(O)$ and as erythrocyte-sensitizing activity (PHA titer; ) after $3 \mathrm{~h}$ incubation at $37^{\circ} \mathrm{C}$.

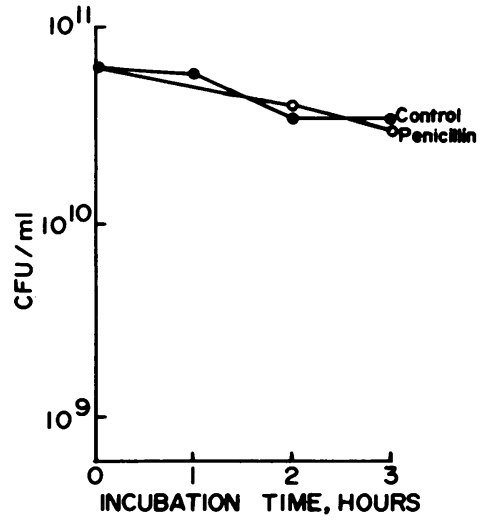

Figure 2 Viability of concentrated streptococcal suspensions in the presence $(O)$ and the absence $(O)$ of penicillin, $1 \mu \mathrm{g} / \mathrm{ml}$.

treatment with penicillin. To determine whether or not penicillin is capable of releasing LTA from group A streptococci in the stationary phase of growth, overnight cultures were sedimented and resuspended in fresh broth to a concentration of $10^{10}$ colony-forming units (CFU) per milliliter. The streptococcal suspension did not increase or decrease in mass during $3 \mathrm{~h}$ of incubation as judged by absorbance measurements at $530 \mathrm{~nm}$. The viability of the concentrated streptococci was not influenced by the penicillin doses employed (see Fig. 1 A). Viability decreased less than one-half $\log _{10}$ after $3 \mathrm{~h}$ of incubation either in the presence or in the absence of penicillin (Fig. 2). The incorporation of $\left[{ }^{3} \mathrm{H}\right]$ thymidine at $37^{\circ} \mathrm{C}$ did not differ within experimental error from that at $4^{\circ} \mathrm{C}(0.3$ vs. $0.15 \%$ of input, respectively).

To confirm the absence of significant bacterial lysis, organisms grown in the presence of $\left[{ }^{3} \mathrm{H}\right]$ thymidine were washed and resuspended at a concentration of $10^{9}$ CFU per ml. Aliquots of the suspension were incubated at $37^{\circ} \mathrm{C}$ in the absence and the presence of $1.0 \mu \mathrm{g} / \mathrm{ml}$ of penicillin, and at $4^{\circ} \mathrm{C}$ in the absence of penicillin. The release of radiolabel was in the same order of magnitude, ranging from $0.6 \%$ at $4^{\circ} \mathrm{C}$ to $2.07 \%$ at $37^{\circ} \mathrm{C}$ in the presence of penicillin (Table I), suggesting that there is insignificant leakage of thymidine-containing materials from the bacteria. These results indicate that under the conditions employed in the following experiments, bacterial multiplication and lysis are negligible.

Effect of penicillin upon release of radiolabel from streptococci grown in the presence of $\left[{ }^{3} \mathrm{H}\right]$ glycerol. The excretion of ${ }^{3} \mathrm{H}$-labeled material increased with time and was markedly stimulated in the presence of penicillin (Fig. 3). The stimulation by penicillin was dose related (see Fig. $4 \mathrm{~A}$ ).

Cultures incubated at $4^{\circ} \mathrm{C}$ excreted less than one-half the amount of ${ }^{3} \mathrm{H}$-labeled material excreted at $37^{\circ} \mathrm{C}$ in the absence of penicillin. The addition of penicillin 
TABLE I

The Absence of Release of $\left[{ }^{3} \mathrm{H}\right]$ Thymidine-Labeled Material from Streptococci Incubated in 20-Fold Concentrated Suspension in the Absence and Presence of Penicillin

\begin{tabular}{lccc}
\hline \multicolumn{1}{c}{ Incubation } & $\begin{array}{c}\text { Total cpm/ } \\
\text { tube }\end{array}$ & $\begin{array}{c}\text { cpm Released } \\
\text { into supernate }\end{array}$ & $\begin{array}{c}\text { Percent } \\
\text { released }\end{array}$ \\
\hline $3 \mathrm{~h}$ at $4^{\circ} \mathrm{C}$ & 59,400 & 358 & 0.6 \\
$3 \mathrm{~h}$ at $37^{\circ} \mathrm{C}$ & 59,400 & 1,028 & 1.73 \\
$\begin{array}{l}3 \mathrm{~h} \text { at } 37^{\circ} \mathrm{C} \text { in the presence } \\
\text { of penicillin, } 1 \mu \mathrm{g} / \mathrm{ml}\end{array}$ & 59,400 & 1,232 & 2.07 \\
\hline
\end{tabular}

produced a further twofold rise in excretion of radiolabel at $37^{\circ} \mathrm{C}$ but not at $4^{\circ} \mathrm{C}$, indicating that excretion stimulated by penicillin was temperature dependent (Table II).

Penicillin-induced loss of the ability of group A streptococci to adhere to epithelial cells. Our previous studies have indicated that LTA is exposed on the surface of group A streptococci and is centrally involved in the adherence of the organisms to oral epithelial cells $(5,6)$. It was of interest, therefore, to determine the effect of penicillin-induced loss of LTA upon adhering ability. Adherence experiments were performed using streptococci that were exposed to penicillin at $37^{\circ} \mathrm{C}$ for $3 \mathrm{~h}$ in the resting phase of growth. Adherence decreased abruptly during treatment of the

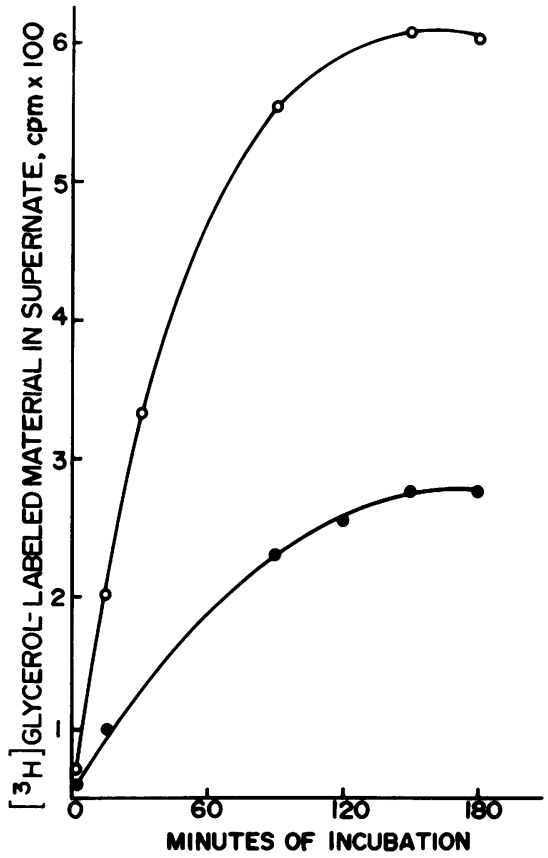

Figure 3 Secretion of $\left[{ }^{3} \mathrm{H}\right]$ glycerol-labeled material into supernates of concentrated suspensions (see text) of group A streptococci during incubation at $37^{\circ} \mathrm{C}$ for $3 \mathrm{~h}$ in the absence (O) and in the presence $(O)$ of $2 \mathrm{U}$ penicillin $/ \mathrm{ml}$.

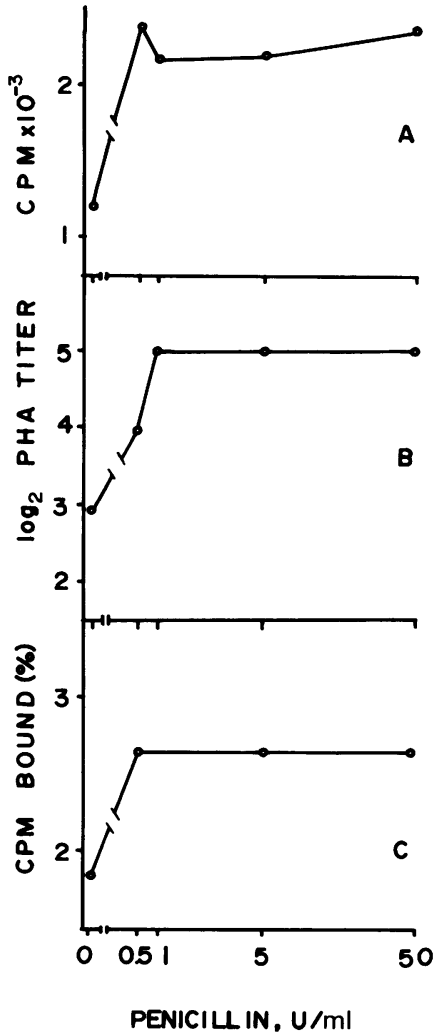

FigURE 4 Enhancement of excretion of LTA by penicillin. Excretion of radiolabel (A) parallels rise in PHA titer (B) and in the binding of radiolabel to oral epithelial cells (C). Suspensions were incubated for $3 \mathrm{~h}$ at $37^{\circ} \mathrm{C}$.

bacteria with concentrations of penicillin above an apparent threshold value of about $1 \mu \mathrm{g} / \mathrm{ml}$ (Fig. 1 B). In control experiments performed at $4^{\circ} \mathrm{C}$, no loss of adhering ability was observed (data not shown). To determine whether the decrease in adhering ability was related to depletion of LTA, the LTA was extracted from streptococci incubated under the same conditions. The extract was then examined for radioactivity and RBCsensitizing activity. The loss of LTA-sensitizing and

TABLE II

Temperature Dependence of Penicillin-Stimulated Release of $\left[{ }^{3} \mathrm{H}\right]$ Glycerol-Labeled Material

\begin{tabular}{lcc}
\hline \multicolumn{1}{c}{ Penicillin } & Temperature & $\begin{array}{c}\text { Radiolabel in } \\
\text { supernate* }\end{array}$ \\
\hline & ${ }^{\circ} \mathrm{C}$ & $\%$ \\
None & 4 & 7.46 \\
$1.14 \mu \mathrm{g} / \mathrm{ml}$ & 4 & 6.28 \\
None & 37 & 18.48 \\
$1.14 \mu \mathrm{g} / \mathrm{ml}$ & 37 & 34.39
\end{tabular}

* Percent of radiolabel in supernate $=(\mathrm{cpm}$ in supernates $) /$ $(\mathrm{cpm}$ in total suspension) $\times 100$. 
binding activities from the bacteria (Fig. $1 \mathrm{C}$ ) paralleled the loss of epithelial cell adhering ability (Fig. 1 B). To detect the excreted LTA, the culture supernates were extracted with chloroform:methanol (2:1), dialyzed against water, lyophilized, and redissolved in a small volume of PBS. These preparations were examined for RBC-sensitizing activity (PHA titer), radioactivity, and the ability of the radioactive materials to bind to oral epithelial cells. The accumulation of radiolabel in the supernate was paralleled by a rise in PHA titer and an increased capacity of the radiolabel to bind to epithelial cells (Fig. 4 A-C).

Analysis of excreted glycerol-containing materials. Further analysis was performed on the concentrated water phase of phenol extracts (see Methods) of supernates of streptococci grown in the absence or in the presence of penicillin. Samples were fractionated on a column of Sepharose 6B. Three distinct peaks of radioactivity were eluted whether or not penicillin had been present (Fig. 5). The peaks were eluted at the positions of known LTA (peak I), deacylated LTA (peak II), and free glycerol (peak III). An additional small peak of radioactive material eluted close to the void volume of the column probably represents a larger micellar form of LTA (2). Each of these peaks was analyzed by SDS polyacrylamide gel electrophoresis, TLC, or paper chromatography, and for the ability of the radiolabeled materials to bind to human RBC and epithelial cells. Peak I obtained from penicillin-free supernates con-

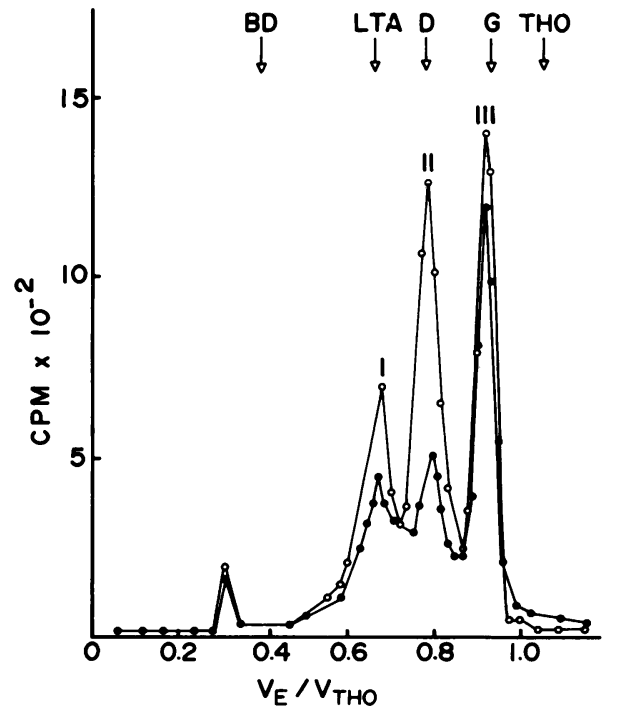

Figure 5 Chromatography on $1.5 \times 90$-cm column of Sepharose $6 \mathrm{~B}$ of supernates obtained from streptococci incubated in the presence $(O)$ and in the absence $(O)$ of $1 \mu \mathrm{g} / \mathrm{ml}$ penicillin. Arrows indicate the elution positions of blue dextran (BD), lipoteichoic acid (LTA), deacylated LTA (D), glycerol (G), and tritiated water (THO). Peaks I, II, and III are further described in the text.

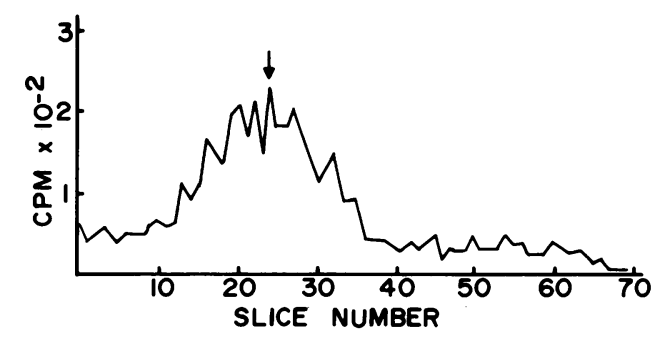

FIGURE 6 SDS polyacrylamide gel electrophoresis of peak I. The end of the stacking gel is represented by slice 1 . Arrow indicates the position of maximal radioactivity obtained from purified radiolabeled LTA.

tained material that migrated in SDS polyacrylamide similar, although in a broader band, to purified LTA (Fig. 6), and bound well to oral epithelial cells (37\%) as well as to RBC (38\%) (Table III). Peak I obtained from supernates in the presence of penicillin was similar except that binding was somewhat less (epithelial cells, $25 \%$ and RBC, 23\%). Peak II migrated to the end of the SDS gel (Fig. 7) and gave a distinct peak on TLC (Fig. 8). Any lipids that may also have escaped into the medium (1) would have been removed from these extracts during the phenol extraction. Peak II obtained both from penicillin-treated and untreated culture supernates showed relatively little binding $(4-8 \%)$ to epithelial cells and RBC (Table III). The relative amount of radiolabeled material eluted in peak II, the position of deacylated LTA, was increased in the pres-

TABLE III

Cell Membrane Binding Properties of Supernate Fractions from Streptococci Grown in the Presence and Absence of Penicillin

\begin{tabular}{|c|c|c|c|}
\hline \multirow[b]{2}{*}{$\begin{array}{l}\text { Radioactive peaks eluted } \\
\text { from Sepharose } 6 B\end{array}$} & \multirow[b]{2}{*}{$\begin{array}{c}\text { Penicillin } \\
\text { in growth } \\
\text { medium }\end{array}$} & \multicolumn{2}{|c|}{$\begin{array}{l}\text { Radiolabel in } \\
\text { fraction binding }\end{array}$} \\
\hline & & $\begin{array}{c}\text { Oral } \\
\text { epithelial } \\
\text { cells }\end{array}$ & $\mathrm{RBC}$ \\
\hline & & \multicolumn{2}{|c|}{$\%$} \\
\hline \multirow[t]{2}{*}{ Peak I } & Absent & 37 & 38 \\
\hline & Present & 25 & 23 \\
\hline \multirow[t]{2}{*}{ Peak II } & Absent & 4 & 8 \\
\hline & Present & 6 & 6 \\
\hline \multirow[t]{2}{*}{ Peak III } & Absent & 4 & 4 \\
\hline & Present & 6 & 5 \\
\hline$\left[{ }^{3} \mathrm{H}\right] \mathrm{LTA}^{*}$ & - & 65 & 76 \\
\hline Deacylated $\left[{ }^{3} \mathrm{H}\right]$ LTA $\ddagger$ & & 2 & 3 \\
\hline
\end{tabular}

* LTA prepared from streptococci grown in the presence of $\left[2-{ }^{3} \mathrm{H}\right]$ glycerol.

$\neq\left[{ }^{3} \mathrm{H}\right]$ LTA was deacylated by mild ammonia hydrolysis in $30 \% \mathrm{NH}_{4} \mathrm{OH}$ at $23^{\circ} \mathrm{C}$ for $24 \mathrm{~h}$ as previously described (6). 


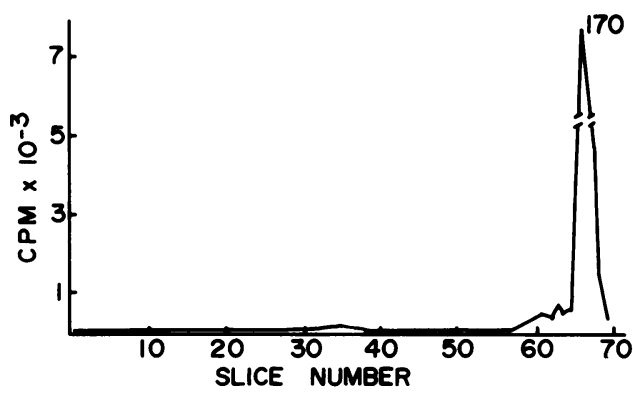

FIGURE 7 SDS polyacrylamide gel electrophoresis of peak II. Radiolabel was detectable in the region of the tracer dye.

ence of penicillin (Fig. 1). The material eluted in peak III appeared as a single peak on TLC (not shown). The materials in this peak bound poorly (4-6\%) to human erythrocytes or epithelial cells (Table III). On paper chromatography (Fig. 8), however, the material resolved into two peaks consistent with the presence of glycerol and glycerol phosphate. The radiolabeled materials in this peak were dialyzable. Penicillin had no apparent influence on the composition of peak III material.

These results indicate that penicillin increased the excretion of LTA, deacylated LTA, and possibly, to a lesser extent, that of glycerol and glycerol phosphate. The radiolabeled material corresponding to deacylated LTA was disproportionately increased in the presence of penicillin.

\section{DISCUSSION}

The main objectives of this research were $(a)$ to study the release of LTA from group A streptococci in the presence of penicillin, and $(b)$ to assess the epithelial cell binding capacity of penicillin-treated organisms. Horne and Tomasz (1) recently demonstrated that streptococci excrete LTA when treated with penicillin during the log phase of growth. Our results show that excretion of LTA occurs in the resting phase of growth as well. The presence of penicillin in the resting cultures enhances excretion twofold with no evidence of

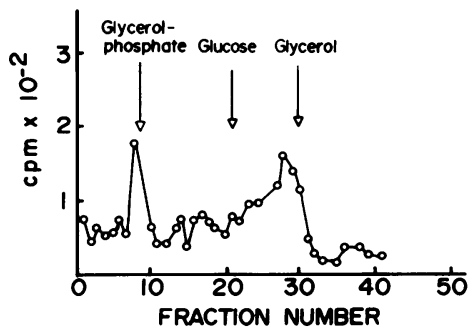

FIGURE 8 Paper chromatography of peak III. The origin is represented by fraction 1 . Arrows represent expected positions for glycerolphosphate (GP), glucose (GLc), and free glycerol (GL). bacterial lysis or killing. Concomitant to the accumulation of LTA in the supernates, we noted a decrease in the content of cell-associated LTA and a marked decrease in the ability of the penicillin-treated streptococci to adhere to human oral epithelial cells.

It is widely accepted that killing or bacteriostasis is the mode of action of antibiotics. Our results suggest that penicillin may indirectly displace streptococci from mucosal surfaces and thus serve as a second mode for the eradication of the infecting organisms. Moreover, displacement or the prevention of adherence may occur independently of the microbicidal activity because loss of adherence occurred in the absence of killing. It appears, however, that penicillin has a definite temperature-dependent effect because neither release of LTA nor loss of adherence were observed at $4^{\circ} \mathrm{C}$. The penicillin-induced loss of LTA from exponentially growing streptococci is also temperature dependent (1). These findings are consistent with recent observations $(4,13)$ suggesting that penicillin is capable of influencing enzymatic systems other than transpeptidation.

Recently it has been demonstrated that exogenous glycerol is incorporated into phosphatidylglycerol in both gram-negative (14) and gram-positive bacteria (2, 15). Phosphatidylglycerol has been shown to serve as the precursor of the backbone of LTA (15). Joseph and Shockman (2) demonstrated that a portion of the incorporated $\left[{ }^{3} \mathrm{H}\right]$ glycerol was released as a material which possessed immunoreactive properties of LTA; they employed antibody specific for the polyglycerolphosphate backbone of teichoic acid. Markham et al. (3) demonstrated that culture supernates of streptococci and lactobacilli contained a substance capable of sensitizing RBC to agglutinate in the presence of antibody to LTA.

In the present study, we have shown that group $\mathrm{A}$ streptococci excrete a material that has RBC-binding as well as sensitizing properties of LTA. The increase in the excretion of radiolabeled material induced by penicillin was paralleled by a rise in the RBC-sensitizing and binding activity indicating that penicillin increased the release of biologically active LTA from group A streptococci; LTA is known to bind spontaneously to a variety of mammalian cell membranes $(6$, 16-18). It should be noted, however, that although penicillin enhanced the excretion of biologically active LTA, there was a disproportionate increase in the ex(retion of deacylated LTA which lacks the ability to bind to membranes. The reasons for the relatively greater increase in excretion of deacylated LTA in the presence of penicillin requires further investigation.

Because streptococcal LTA has been shown to mediate adherence of the organisms to human epithelial cells $(5,6)$, it would be reasonable to assume that loss of bacterial adherence was a result of depletion of LTA from streptococci under the influence of penicillin. 
This notion is strengthened by the fact that loss of adherence paralleled loss of LTA from the streptococci.

These observations suggest the possibility that penicillin may influence the colonization of the pharynx not only by killing penicillin-sensitive organisms but also by stimulating the excretion of materials mediating adherence, which may play a central role in the bacterial ecology on mucosal surfaces.

\section{ACKNOWLEDGMENTS}

We are deeply indebted to Dr. A. Tomasz and his co-workers at The Rockefeller University in New York for their assistance in performing some of the analytical procedures. We also wish to thank Dr. Itzhak Ofek for helpful suggestions, Robert J. Curtis for excellent technical assistance, and Mrs. Johnnie Smith for typing the manuscript.

These studies were conducted under projects 0805-02 and 0805-04 from the Veterans Administration, and research grants AI-13550 and AI-10085 from the U.S. Public Health Service.

\section{REFERENCES}

1. Horne, D., and A. Tomasz. 1977. Tolerant response of Streptococcus sanguis to beta lactams and other cell wall inhibitors. Antimicrob. Agents Chemother. 11: 888-896.

2. Joseph, R., and G. D. Shockman. 1975. Synthesis and excretion of glycerol teichoic acid during growth of two streptococcal species. Infect. Immun. 12: 333-338.

3. Markham, J. L., K. W. Knox, A. J. Wicken, and M. J. Hewett. 1975. Formation of extracellular lipoteichoic acid by oral streptococci and lactobacilli. Infect. Immun. 12: 378-386.

4. Tomasz, A., and S. Waks. 1975. Mechanism of action of penicillin: triggering of the pneumococcal autolysis enzyme by inhibitors of cell wall synthesis. Proc. Natl. Acad. Sci. U. S. A. 72: 4162-4166.

5. Beachey, E. H., and I. Ofek. 1976. Epithelial cell binding of group A streptococci by lipoteichoic acid on fimbriae denuded of M protein. J. Exp. Med. 143: 759-771.

6. Ofek, I., E. H. Beachey, W. Jefferson, and G. L. Campbell. 1975. Cell membrane-binding properties of group A streptococcal lipoteichoic acid. J. Exp. Med. 141: 990-1003.

7. Beachey, E. H., and G. H. Stollerman. 1971. Toxic effects of streptococcal $\mathrm{M}$ protein on platelets and polymorphonuclear leukocytes in human blood. J. Exp. Med. 134: $351-365$.

8. Moskowitz, M. 1966. Separation and properties of a red cell sensitizing substance from streptococci. J. Bacteriol. 91: $2200-2204$.

9. Weber, K., and M. Osborn. 1969. The reliability of molecular weight determinations by dodecylsulfate. J. Biol. Chem. 224: 4406-4412.

10. Skipski, V.P., and M. Barclay. 1969. Thin layer chromatography of lipids. Methods Enzymol. 1: 530-597.

11. Alkan, M., I. Ofek, and E. H. Beachey. 1977. Adherence of pharyngeal and skin strains of group A streptococci to human skin and oral epithelial cells. Infect. Immun. 16: $555-5.57$.

12. Gibbons, R. J., and J. Van Houte. 1971. Selective bacterial adherence to oral epithelial surfaces and its role as an ecological determinant. Infect. Immun. 3: 567-573.

13. Rogers, H. J., and C. W. Forsberg. 1971. Role of autolysis in the killing of bacteria by some bacterial antibiotics. J. Bacteriol. 108: 1235-1243.

14. VanGolde, L. M. G., H. Shulman, and E. P. Kennedy. 1973. Metabolism of membrane phospholipids and its relation to novel class of oligosaccharides in Escherichia coli. Proc. Natl. Acad. Sci. U. S. A. 70: 1368-1372.

15. Emdur, L. I., and T. H. Chiu. 1974. Turnover of phosphotidylglycerol in Streptococcus sanguis. Biochem. Biophys. Res. Commun. 59: 1137-1144.

16. Chorpenning, F. W., and H. B. Stamper. 1973. Spontaneous absorption of teichoic acid to erythrocytes. Immunochemistry. 10: 15-20.

17. Knox, K. W., and A. J. Wickens. 1973. Immunological properties of teichoic acids. Bacteriol. Rev. 37: 215-257.

18. Stewart, F. S., and W. T. Martin. 1962. Adsorption of a streptococcal red cell sensitizing antigen to various tissues. J. Pathol. Bacteriol. 84: 251-253. 